\title{
The use of Saccharomyces cerevisiae for removing cadmium(II) from aqueous waste solutions
}

\author{
Manal Tawfeek El-Sayed \\ Department of Botany, Faculty of Science, Zagazig University, Zagazig, Egypt. \\ Accepted 5 July, 2012
}

\begin{abstract}
The biosorption of cadmium(II) on live and dead biomass of Saccharomyces cerevisiae was investigated with respect to the adsorption conditions. The biosorption mechanism was investigated by energy dispersive X-ray analysis (EDAX) and transmission electron microscope (TEM). The effects of the biosorbent dose, initial metal ion concentration, initial $\mathrm{pH}$ and contact time were studied. The optimum conditions for cadmium(II) biosorption were found to be $3 \mathrm{~g} / \mathrm{L}, 250 \mathrm{mg} / \mathrm{L}$ and 6.0 , respectively, for biosorbent dose, initial metal ion concentration and initial pH. Cadmium(II) biosorption by dead cells was a fast process. Under these conditions, the maximum biosorption capacity of the dead biomass was obtained to be $55 \mathrm{mg} / \mathrm{g}$, while that of live biomass was $36 \mathrm{mg} / \mathrm{g}$. TEM observations indicated the presence of cadmium (II) deposits intracellularly and extracellularly. EDAX examinations showed that cadmium(II) was exchanged with the element (aluminum) present on the surface of native cells of $S$. cerevisiae, thereby suggesting the occurrence of bioadsorption, ion exchange and complexation. Cadmium(II) biosorption capacity on dead cells was enhanced by ethanol treatment and alginate immobilization. Overall, the results showed that the ethanol-treated, alginate-immobilized biomass was capable of removing cadmium(II) from wastewater samples.
\end{abstract}

Key words: Biosorption, Saccharomyces cerevisiae, cadmium(II), immobilization, chemical treatment

\section{INTRODUCTION}

In recent years, heavy metal pollution has become one of the most serious environmental problems. The presence of heavy metals even in traces is toxic and detrimental to both flora and fauna (Volesky, 1990). Industrially, cadmium(II) is produced solely as a by-product from the extraction of zinc and lead. It is used in rechargeable batteries, specialized electronic equipment, bearing alloys, pigment (yellow and red) for ceramic glazes, paints and plastics. It is also present in phosphate fertilizers and fungicides (Ayres, 1992). The concern arises because it accumulates in particular food species, with potential consequences to human health (Sola et al., 1998). Cadmium(II) has been correlated with hypertension, reduced life span, prostate cancer, suppression of testicular function and disruption of a number of enzyme systems (Hallenbeck, 1986). In 1997,

*Corresponding author. E-mail: tawfeek.manal1@gmail.com. Tel: 00201117132152 . Fax: 0020552381332.
cadmium(II) was ranked number 7 by the Agency for Toxic Substances and Disease Registry/Environmental protection Agency "Top 20 Hazardous Substances Priority List" (Liao and Freedman, 1998).

Several methods are being used for the removal heavy metal ions from aqueous wastes, such as chemical precipitation, ion exchange, electrochemical treatment, membrane technologies and adsorption on activated carbon, etc (Matheickal and Yu, 1999). Each of these methods has its own advantages and disadvantages. Biosorption utilizes both living and dead biological cells, as well as chemically pretreated microorganisms. The metal ion uptake by living and dead cells can consist of two different modes. The first uptake mode is independent of cell metabolic activity and involves surface binding of metal ions to cell walls and extracellular material. This is referred to biosorption or passive uptake. The second mode of metal uptake into the cell across the cell membrane is referred to intercellular uptake, active uptake or bioaccumulation (Viraraghavan and Srinivasan, 2011). The efficiency by 
which dead cells act as sorbent of metal ions may be greater than that of living cells and confirm its wider acceptability (Awoflou et al., 2006).

Saccharomyces cerevisiae in different forms such as living cell/dead cell (Horikoshi et al., 1981), immobilized cell/free cell (Veglio and Beolchinin, 1997) and wild type/mutant type (Marques et al., 1999) has been studied in biosorption research. S. cerevisiae is widely used in food and beverage manufacturing, and easily grown in cheap medium. It is also a by-product and can be obtained in large quantity as a waste of fermentation industry, and it is easily manipulated at a molecular level (Wang and Chen, 2006). Pretreatment and killing of biomass either by physical or chemical treatments (Brady et al., 1994; Huang et al., 1990; Zouboulis et al., 1999) or cross linking (Leusch et al., 1995) are known to improve the biosorption capacity of biomass. According to many researchers, the chemical treatment methods may provide better results owing to change in cell wall chemistry of the biosorbent (Kapoor et al., 1999). Yan and Viraraghavan (2000) reported that alkaline treatment could enhance metal binding by the biomass.

The investigation of the performance of free cells is fundamental for the industrial application of biosorption because it gives information about the equilibrium of the process (Veglio and Beolchini, 1997). Immobilization offers several advantages, including minimal clogging in continuous systems (Bayramoglu et al., 2003). The cells are easy to separate from the reaction system and can be regenerated (Annadurai et al., 2007). However, immobilized biosorbents have major disadvantages such as cost, poor mechanical strengths, instability at low $\mathrm{pH}$, cell leakage and diffusional limitations (Aksu and Gonen, 2004). The present study investigates the use of live and dead $S$. cerevisiae either free or immobilized in the removal of cadmium(II) from aqueous waste solutions. Also, the reuse of immobilized biomass was studied.

\section{MATERIALS AND METHODS}

\section{Preparation of biosorbent}

Culture of $S$. cerevisiae AUMC 3875 was obtained from Assuit University Mycological Center. A slant culture was first conducted for $24 \mathrm{~h}$ at $28^{\circ} \mathrm{C}$ and then followed by a two-step culture enlargement. The slant culture medium Yeast Extract Peptone Dextrose (YEPD) which consisted of $1 \%$ yeast extract, $2 \%$ peptone, $2 \%$ dextrose, $2 \%$ agar was used. The first enlarged culture was carried out by inoculating $S$. cerevisiae cells from a slant culture into $250 \mathrm{ml}$ cell culture bottle with $50 \mathrm{ml}$ liquid culture medium, and then incubated in an incubator shaker (Model SK- 757, Lafayette, CA 94549, USA) at $120 \mathrm{rpm}$ for $24 \mathrm{~h}$ at $28^{\circ} \mathrm{C}$. In the following second enlarged culture, $1 \mathrm{ml} S$. cerevisiae cell suspension obtained from the first enlarged culture was inoculated into a $500 \mathrm{ml}$ cell culture bottle with $100 \mathrm{ml}$ liquid culture medium and incubated at $120 \mathrm{rpm}$ for $24 \mathrm{~h}$ at $28^{\circ} \mathrm{C}$. The cell suspension was centrifuged (Model LN 800, Akyuet 06287, Ankara, Turkey) at $4000 \mathrm{rpm}$ for $10 \mathrm{~min}$, agitated at $120 \mathrm{rpm}$ and washed with deionized water several times until the supernatant liquid was clear (Zan et al., 2011). One part of the biomass was autoclaved (Model MSW-101YDX, India) at $121^{\circ} \mathrm{C}$ for $15 \mathrm{~min}$, then dried at $80^{\circ} \mathrm{C}$ to a constant weight to prepare the dead cells and the other part was directly used as live cells. Cell viability was assessed by conventional spread plate technique using distilled deionized water as a diluent (Suh et al., 1998).

\section{Chemicals}

The stock solution was prepared using cadmium chloride $\left(\mathrm{CdCl}_{2}\right)$ (Merck) and diluted as appropriate in deionized water.

\section{Experimental methods}

\section{Determination of minimum inhibitory concentration (MIC)}

Tolerance to cadmium(II) was determined as the minimum inhibitory concentration (MIC) against $S$. cerevisiae. YEPD medium was prepared and amended with various amounts of cadmium to achieve the desired concentrations of $0,100,200,300,400,500$, $600,700,800,900$ and $1000 \mathrm{mg} / \mathrm{L}$. The plates were inoculated with $0.5 \mathrm{ml}$, of about $10^{7} \mathrm{CFU} / \mathrm{ml}$ of $S$. cerevisiae cells and incubated at $28^{\circ} \mathrm{C}$ for $48 \mathrm{~h}$. MIC was defined as the minimum inhibitory concentration of the heavy metal that inhibits the visible growth of S. cerevisiae

The prepared microorganism suspension of live and dead cells $(50 \mathrm{ml}$ ) with concentrations 2, 3, 4 and $5 \mathrm{~g} / \mathrm{L}$ (with respect to cell dry weight) were added to $250 \mathrm{ml}$ Erlenmeyer flasks separately. Aliquots $(50 \mathrm{ml})$ of cadmium chloride solution prepared at twice the desired concentration ( $250 \mathrm{mg} / \mathrm{L})$ were added to each flask, and flasks were shaken in an incubator shaker at $28^{\circ} \mathrm{C}$ and $120 \mathrm{rpm}$ (Suh et al., 1998). The $\mathrm{pH}$ was adjusted to 6 with an aqueous solution of $0.1 \mathrm{~N} \mathrm{HCl}$ and $1 \mathrm{~N} \mathrm{NaOH}$. Samples were centrifuged and the supernatants were analyzed by atomic absorption spectrophotometer (Model Unicam 969, UK, Centric Laboratory of Agriculture Faculty, Zagazig University) for determination of final concentration of cadmium(II).

To evaluate the effect of initial metal ion concentration on adsorption behavior of cadmium(II) by live and dead biomass, aliquots $(50 \mathrm{ml})$ of 50,150 and 250,300 and $350 \mathrm{mg} / \mathrm{L}$ concentrations of cadmium chloride were added to $3 \mathrm{~g} / \mathrm{L}$ biomass in $250 \mathrm{ml}$ Erlenmeyer of flasks. Kinetic experiments for the biosorption of cadmium(II) were conducted at different time intervals of 0.17 , $0.5,1.0,1.5,2.0,3.0,6.0,12.0$ and $24.0 \mathrm{~h}$ for the live and dead cells of $S$. cerevisiae in an incubator shaker at $28^{\circ} \mathrm{C}$ and $120 \mathrm{rpm}$. An adsorbent concentration of $3 \mathrm{~g} / \mathrm{L}$ of yeast biomass (with respect to dry weight) was added to $50 \mathrm{ml}$ of cadmium chloride solution containing an initial metal ion concentration of $250 \mathrm{mg} / \mathrm{L}$. The effect of $\mathrm{pH}$ on biosorption of cadmium(II) by live and dead cells was investigated in the $\mathrm{pH}$ ranges of 2.0 to 7.0. A biomass of $3 \mathrm{~g} / \mathrm{L}$ was added to $50 \mathrm{ml}$ of cadmium chloride solution containing an initial metal concentration of $250 \mathrm{mg} / \mathrm{L}$. To avoid shifts in $\mathrm{pH}$ due to biomass addition, the $\mathrm{pH}$ was adjusted with an aqueous solution of $0.1 \mathrm{~N} \mathrm{HCl}$ or $1 \mathrm{~N} \mathrm{NaOH}$ after the solution had been in contact with the adsorbent.

\section{Biosorption data evaluation}

The amount of metallic ion biosorbed per gram of biomass (q) was determined using the following equation:

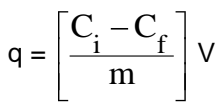

Where, q (metal uptake, $\mathrm{mg} / \mathrm{g}$ ) is the amount of ions adsorbed on 
the biosorbent, $\mathrm{V}(\mathrm{ml})$ is the volume of reaction mixture, $\mathrm{C}_{i}$ and $\mathrm{C}_{f}$ $(\mathrm{mg} / \mathrm{L})$ are the initial and final concentration of metal in the solution, respectively and $\mathrm{m}(\mathrm{g})$ is the concentration of the used biosorbent on dry basis.

\section{Transmission electron microscopy (TEM)}

To prepare the samples for TEM, untreated cells and the heavy metal adsorbed cells were washed three times with $\mathrm{pH} 7.2$ phosphate buffer and fixed with $2.5 \%(\mathrm{v} / \mathrm{v})$ glutaraldehyde for $1.5 \mathrm{~h}$ and with $1 \%$ osmium tetraoxide for another $1.5 \mathrm{~h}$. After fixation, samples were washed three times with a buffer solution and dehydrated with ethyl alcohol and propylene oxide. Spurr resin was put into the dehydrated samples, and then left at $28^{\circ} \mathrm{C}$ for $12 \mathrm{~h}$. TEM blocks were produced by adding new resin and stored in a drying oven at $60^{\circ} \mathrm{C}$ for $48 \mathrm{~h}$. Blocks were sectioned with a diamond knife (ultramicrotome RMC USA) into ultrathin sections about $70 \mathrm{~nm}$ (Park et al., 2003). These ultrathin sections were contrasted with uranyl acetate (Sptempack and Ward, 1969) followed by lead citrate (Reynolds, 1963) each for $30 \mathrm{~min}$ and examined on electron microscope (JEM -1010, JEOL, Seoul, Korea).

\section{Energy dispersive $\mathrm{X}$ - ray analysis (EDAX)}

Dead and live biomass obtained by centrifugation from the uptake experiments were washed three times by deionized water and were dried at $60^{\circ} \mathrm{C}$ to constant weight. The untreated cells were taken as a control. Heavy metal fractions in the samples were examined by the environmental scanning electron microscope (Model Philips XL30 ESEM, Holland) coupled with $X$ - ray energy dispersive analysis (EDAX) at the Laboratory of Nuclear Material Authority (NMA) Cairo, Egypt.

\section{Chemical treatments of yeast biomass}

Ethanol treated biomass was prepared by suspending $5 \mathrm{~g}$ of yeast cells in $100 \mathrm{ml}$ of $700 \mathrm{~g} / \mathrm{L}$ ethanol solution for $20 \mathrm{~min}$ at room temperature. Caustic treated cells were prepared by mixing $5 \mathrm{~g}$ of yeast cells with $100 \mathrm{ml}$ of $40 \mathrm{~g} / \mathrm{L} \mathrm{NaOH}$ and sterilizing the resulting solution at $121^{\circ} \mathrm{C}$ for $15 \mathrm{~min}$. After $\mathrm{NaOH}$ and ethanol treatments, yeast cells were collected by centrifugation. Then cells treated with $\mathrm{NaOH}$ were washed several times to remove excess $\mathrm{NaOH}$. All the treated biomass were dried at $80^{\circ} \mathrm{C}$ to a constant weight and then powdered in a mortar and pestle (Göksungur et al., 2005). Afterward, the treated biomass was added at 2, 3, 4 and $5 \mathrm{~g} / \mathrm{L}$ into $250 \mathrm{ml}$ Erlenmeyer flasks. Aliquots $(50 \mathrm{ml})$ of cadmium chloride solution $(250 \mathrm{mg} / \mathrm{L})$ were added to each flask and left $30 \mathrm{~min}$ at $28^{\circ} \mathrm{C}$ and $120 \mathrm{rpm}$. The $\mathrm{pH}$ was adjusted to 6 using aqueous solution of $1 \mathrm{~N} \mathrm{NaOH}$ or $0.1 \mathrm{~N} \mathrm{HCl}$.

\section{Cadmium(II) biosorption by ethanol-treated immobilized yeast biomass}

To each well of a percolating plate, $50 \mathrm{mg}$ of ethanol-treated biosorbent was added, followed by $4 \%$ sodium alginate of high viscosity. Next, a drop of $0.25 \mathrm{M} \mathrm{CaCl}_{2}$ was added to each well separately to form beads. The beads were collected and air-dried to yield pellets. Dried pellets each containing $50 \mathrm{mg}$ biosorbent biomass were added to conical flasks to get final biomass concentration of $2,3,4$ and $5 \mathrm{~g} / \mathrm{L}$. A constant $\mathrm{pH}$ of 6 and time of contact $30 \mathrm{~min}$ at $28^{\circ} \mathrm{C}$ and $120 \mathrm{rpm}$ were used (El-Morsy, 2004).

\section{Desorption experiment}

Cadmium(II) loaded ethanol-treated immobilized beads after biosorption were transferred into $50 \mathrm{ml}$ of the elutants; $0.5 \mathrm{~mol} / \mathrm{L}$ $\mathrm{HCl}$ and $1 \mathrm{mmol} / \mathrm{L}$ ethylenediaminetetraacetic acid (EDTA) solutions and kept for $24 \mathrm{~h}$ (Zan et al., 2011). The residual metal concentrations in solutions were determined.

Biosorption of cadmium(II) from polluted sites by ethanoltreated immobilized yeast cells

Wastewater samples were collected from industrial area of tenth of Ramadan, a town located $40 \mathrm{~km}$ east of Sharkia Governorate that is known for its industry. Temperature $\left({ }^{\circ} \mathrm{C}\right), \mathrm{pH}$, and dissolved cadmium(II) (mg/L) of wastewater were measured (APHA, 1989). Ethanol-treated immobilized yeast cells were maintained in the conical flasks containing $100 \mathrm{ml}$ of effluent at $\mathrm{pH}$ 6. After $30 \mathrm{~min}$ incubation, the residual metal concentration was determined by atomic absorption spectrophotometer.

\section{RESULTS AND DISCUSSION}

\section{Heavy metal resistance}

Survival of microorganisms in the presence of toxic metals depends on intrinsic biochemical and structural properties, physiological and/or genetic adaptation, environment modification of metal speciation, availability and toxicity (Cooksey, 1993; Blackwell et al., 1995). S. cerevisiae was found to be resistant to cadmium(II) up to $900 \mathrm{mg} / \mathrm{L}$ using YEPD agar medium. The use of YEPD agar medium to estimate the resistance level of yeast against heavy metals was also reported by many researchers (Dar and Shakoori, 1999; Pearce and Sherman, 1999; Lee and Ueom, 2001). Unfortunately, some chemical interactions between the metal and the medium components may overestimate the resistance level of the microbe. Shakoori et al. (2000) reported the MIC of cadmium(II) as $60,70,250 \mathrm{mg} / \mathrm{ml}$ for cadmium resistant yeasts.

One of the parameters that greatly affect the biosorption capacity is the concentration of the biosorbents. With the fixed cadmium(II) concentration of $250 \mathrm{mg} / \mathrm{L}$, the uptake of cadmium(II) decreased with increasing concentration of living and dead cells and the highest cadmium uptake $(55 \mathrm{mg} / \mathrm{g}$ for dead cells and 36 $\mathrm{mg} / \mathrm{g}$ for live cells), was observed at biomass concentration $3 \mathrm{~g} / \mathrm{L}$ (Figure 1). Tsekova and Petrov (2002) found that at lower biomass concentration of Rhizopus delemar mycelia at a given metal concentration, the metal biosorbent ratio was enhanced and thus metal uptake is increased as long as the biosorbent is not saturated. The decreasing metal uptake at higher biosorbent dosage could be explained by considering a partial cell aggregation that took place at high biosorbent concentrations. This results in the three dimensional structure of the cell wall and the internal linkages between the reactive groups $\left(\mathrm{COO}^{-}\right.$and $\left.\mathrm{NH}_{3}{ }^{+}\right)$, 


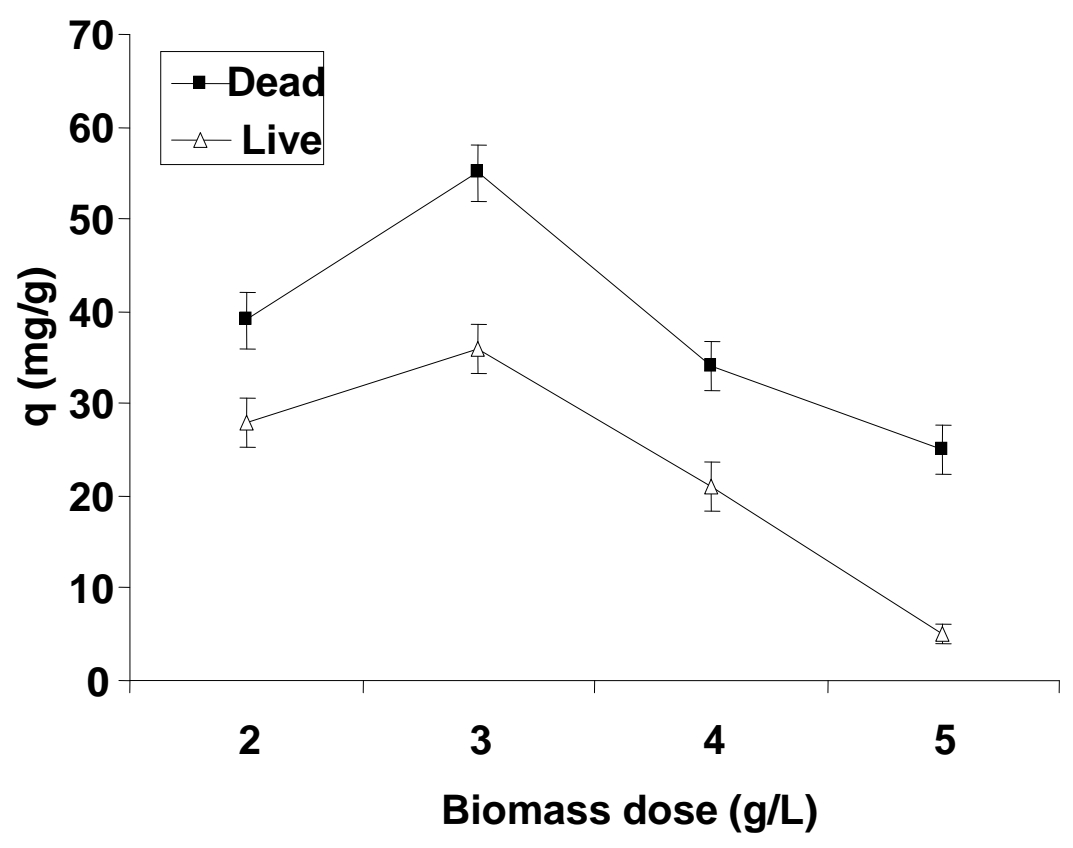

Figure 1. Effect of biosorbent concentration (m) on cadmium(II) uptake capacity of live and dead $S$. cerevisiae. Biosorption conditions: initial metal ion concentration $\left(\mathrm{C}_{\mathrm{i}}\right)=250 \mathrm{mg} / \mathrm{L} ; \mathrm{pH}=6.0$ (for dead) at $\mathrm{pH}=5.0$ (for live); agitation rate $=120 \mathrm{rpm}$; contact time $(\mathrm{t})=0.5 \mathrm{~h}$ (for dead cells) and $3 \mathrm{~h}$ (for live cells).

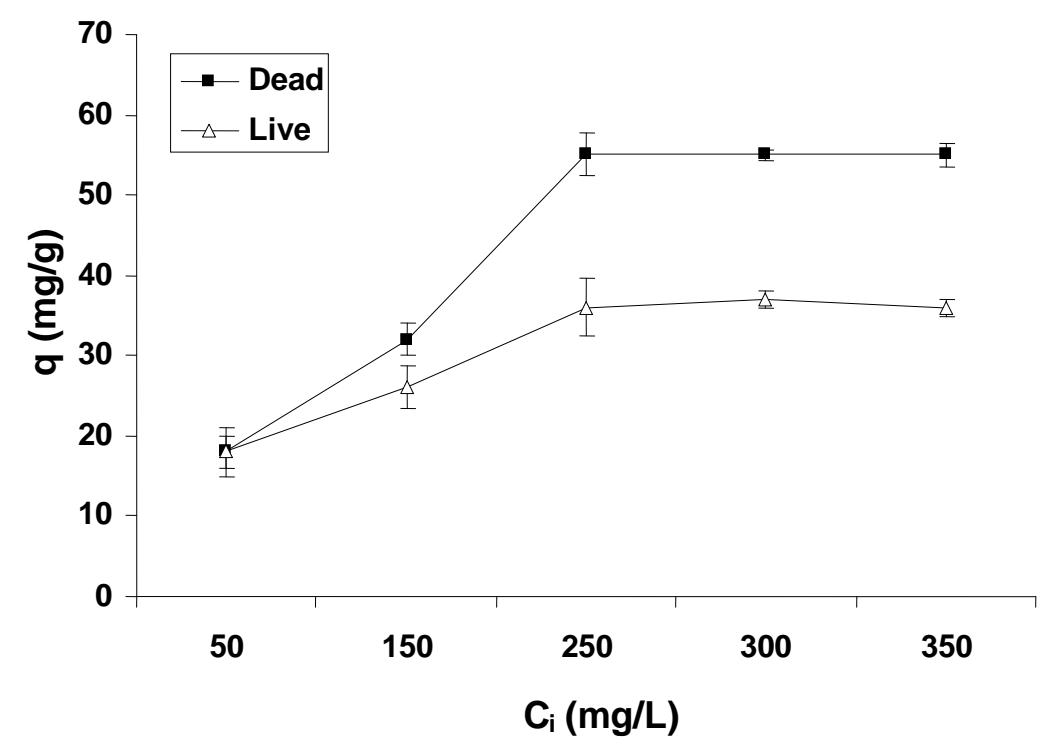

Figure 2. Effect of initial metal ion concentration $\left(\mathrm{C}_{\mathrm{i}}\right)$ on cadmium(II) uptake capacity of live and dead S. cerevisiae. Biosorption conditions: $m=3.0 \mathrm{~g} / \mathrm{L}$; $\mathrm{pH}=6.0$ (for dead) at $\mathrm{pH}=5.0$ (for live); agitation rate $=120 \mathrm{rpm}$ and $\mathrm{t}=0.5 \mathrm{~h}$ (for dead cells) and $3 \mathrm{~h}$ (for live cells).

thus reducing cadmium(II) diffusion through the structure and the accessibility of the binding sites for adsorption (Incharoensakdi and Kitjaharn, 2002). It was also observed that with increasing biosorbent dosage up to 5 $\mathrm{g} / \mathrm{L}$, the uptake capacity of live cells $(5 \mathrm{mg} / \mathrm{g})$ was much greatly reduced than that of dead cells $(25 \mathrm{mg} / \mathrm{g})$. This may be due to the greater tendency of live cells to aggregate.
The cadmium(II) uptake capacities of live and dead cells of $S$. cerevisiae were presented as a function of the initial concentration of cadmium(II) (Figure 2). Cadmium(II) uptake by live and dead cells of $S$. cerevisiae increased with increasing initial cadmium(II) concentration and reached a maximum value at 250 $\mathrm{mg} / \mathrm{L}$. Beyond the concentration of $250 \mathrm{mg} / \mathrm{L}$, 


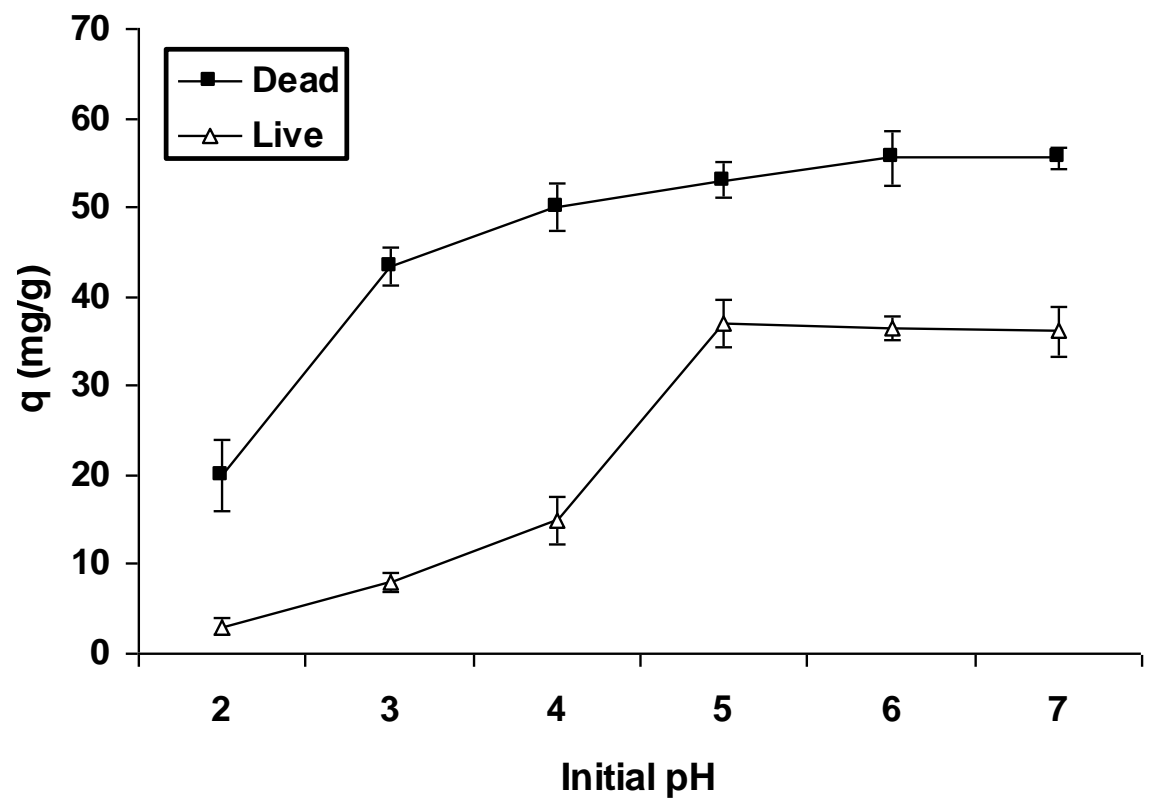

Figure 3. Effect of initial $\mathrm{pH}$ on cadmium(II) uptake capacity of live and dead $S$. cerevisiae. Biosorption conditions: $\mathrm{m}=3.0 \mathrm{~g} / \mathrm{L} ; \mathrm{C}_{\mathrm{i}}=250 \mathrm{mg} / \mathrm{L}$; agitation rate $=120 \mathrm{rpm}$ and $\mathrm{t}=0.5 \mathrm{~h}$ (for dead cells) and $3 \mathrm{~h}$ (for live cells).

the uptake capacity of the biosorbent remained relatively unchanged. This was possibly due to saturation of metal binding sites on the biosorbent. As a matter of fact, biosorptive capacity of metal ions is reported to be related to the ratio of the concentration of initial metal ions to the concentration of the biomass (Wang and Chen, 2006). For biosorption of heavy metal ions, $\mathrm{pH}$ is one of the most important environmental factors. The $\mathrm{pH}$ value of solution strongly influences not only the site dissociation of the biomass surface, but also the solution chemistry of the heavy metals: hydrolysis, complexation by organic and/or inorganic ligands, redox reactions, precipitation, the speciation and the biosorption availability of the heavy metals (Esposito et al., 2002).

Cadmium(II) uptake capacities of live and dead cells were presented as a function of the initial $\mathrm{pH}$ (Figure 3). The optimum initial pH for biosorption of cadmium(II) onto live and dead cells of $S$. cerevisiae was observed at $\mathrm{pH}$ 6.0. However, the cadmium(II) removal efficiency of $S$. cerevisiae dropped sharply at $\mathrm{pH} \leq 3$ in case of live cells. This may be due to protein denaturation at low $\mathrm{pH}$ (Rothschild and Mancinelli, 2001). However, an increase in cadmium(II) removal by live and dead cells was observed when the $\mathrm{pH}$ was raised up to 5.0 and 6.0, respectively.

At low $\mathrm{pH}$, cell wall ligands are closely associated with the hydronium ions $\left[\mathrm{H}_{3} \mathrm{O}\right]^{+}$and restrict the approach of metal cations as a result of the repulsive force. At higher $\mathrm{pH}$, divalent positive ions are suitable to interact with negatively charged groups in biomass. On the other hand, the outer layer of the cell wall of $S$. cerevisiae consists of a protein coat, which can cause a charge through dissociation of ionizable side groups of the amino acids. The ionic state of ligands such as carboxyl, phosphate, imidazole and amino groups will promote reaction with the positively charged metal ions (Özer and Özer, 2003).

Figure 4 shows the effects of contact time for the biosorption of cadmium(II) by live and dead cells of $S$. cerevisiae. Cadmium(II) biosorption by dead cells was most rapid in the initial period and the maximum uptake was achieved after 0.5 and $3.0 \mathrm{~h}$ by dead and live cells, respectively. This was followed by residual and slower additional metal deposition, conceivably indicating a secondary metal binding mechanism. In general, the biosorption capacity and the removal efficiency of metal ions by $S$. cerevisiae become higher with prolonging the contact time (Wang and Chen, 2006). Ferraz et al. (2004) optimized the sorption time for chromium(III) by $S$. cerevisiae; their results showed that a 30 min sorption period is the best option to ensure the metal removal from solution and good recovery from biosorbent.

The TEM observations of the original $S$. cerevisiae prior to cadmium(II) accumulation were compared with live and dead cells after cadmium(II) accumulation (Figure 5A to D). In the case of cadmium(II) biosorption by the live $S$. cerevisiae (Figure $5 \mathrm{~B}$ and $\mathrm{C}$ ), the electron-dense metal deposits were predominantly accumulated onto both the cell surface and the inner cellular parts. The precipitation outside the cell seemed to be the first step in the cell's battle with cadmium(II). Extracellular polysaccharides bind large quantities of metal because of the negatively charged groups present (Scott and Plamer, 1995). Contrary to this, 


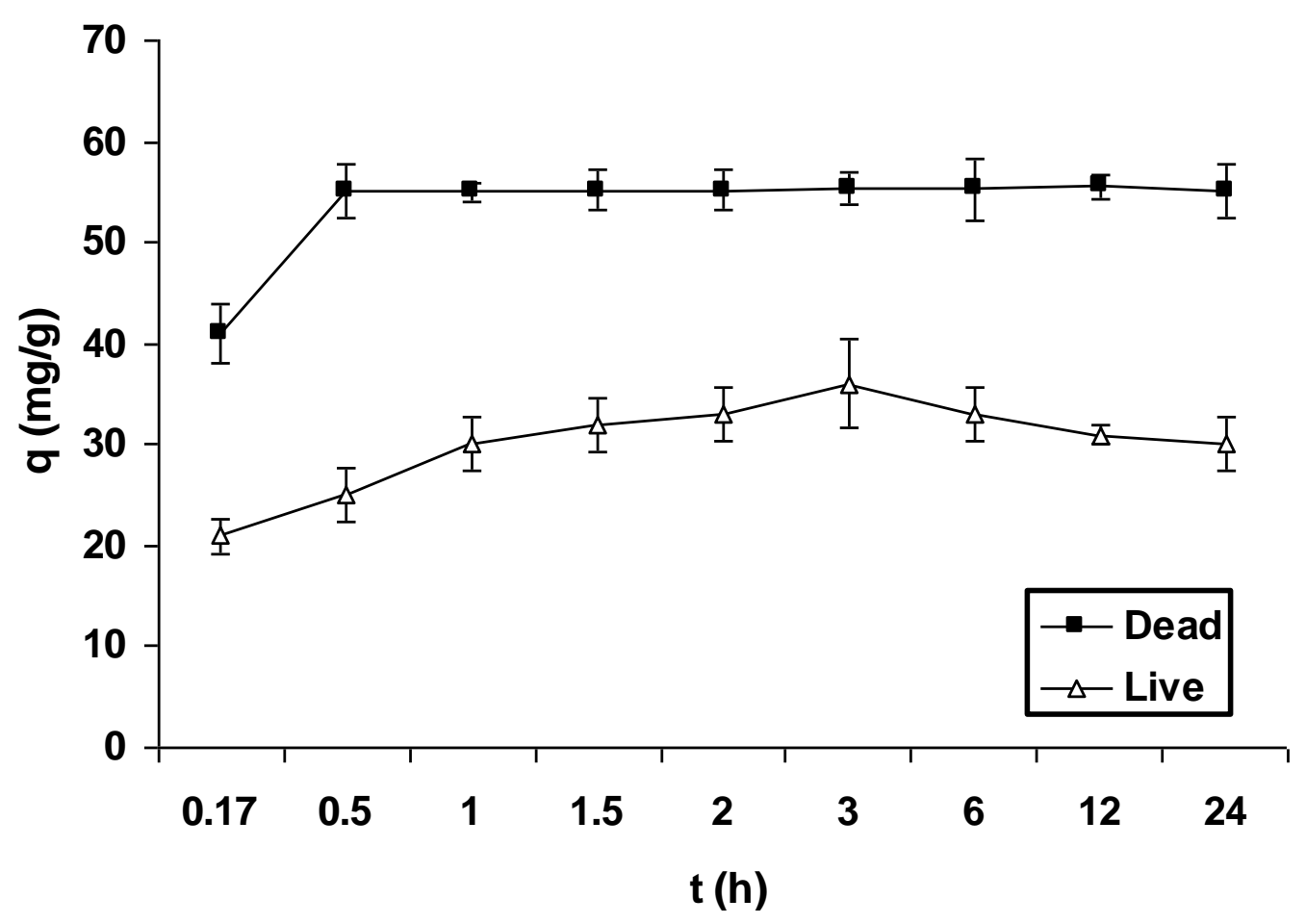

Figure 4. Effect of initial contact time (t) on cadmium(II) uptake capacity of live and dead $S$. cerevisiae. Biosorption conditions: $\mathrm{m}=3.0 \mathrm{~g} / \mathrm{L} ; \mathrm{C}_{\mathrm{i}}=250 \mathrm{mg} / \mathrm{L} ; \mathrm{pH}=6.0$ (for dead cells) and $\mathrm{pH}=5.0$ (for live cells) and agitation rate $=120 \mathrm{rpm}$.

Volesky et al. (1993) detect no cadmium(II) deposits on the outer wall of yeast cells and observe that some cells exhibited no deposition at all. Most cells observed by TEM had intracellular metal deposits in the form of irregular granules in the cytoplasm (Figure 5B). These might be a deposition of metal complexes as a mean of compartmentation of these ions inside the cell. Quite similar observations were also found by Shao and Sun (2007), Magyarosy et al. (2002), and Hefnawy et al. (2009). Their results suggest that the compartmentation is essential for metal detoxification (Gonzalez et al., 2008).

Moreover, plasmolysis could be also observed (Figure $5 \mathrm{C})$ due to the high toxicity of cadmium(II). Its toxic effects may be summed up under the general headings "thiol-binding and protein denaturation", "interaction with calcium metabolism and membrane damage" and "interaction with zinc metabolism or loss of a protective function" (Nies, 1999). In comparison with control cells, the cadmium(II)-adsorbed $S$. cerevisiae cells showed an undulating plasma membrane generating vesicles due to invagination (Figure $5 \mathrm{C}$ ). This retraction may suggest the loss of plasma membrane turgidity and may be related to the exocytosis to the periplasmic space (Osumi, 1998). On the contrary, in the case of dead cells (Figure 5D) most of cadmium(II) was observed around the fragments of cell wall, on the inner face of plasma membrane, on cytoplasm and in between the latter two. In this connection, Machado et al. (2008) reported that the increase of nickel removed by dead cells of $S$. cerevisiae could likely be attributed to the exposition of further metal binding sites present inside the cells.

In this study, sodium ( $\mathrm{Na})$, magnesium $(\mathrm{Mg})$, aluminium $(\mathrm{Al})$, silicon $(\mathrm{Si})$, phosphorus $(\mathrm{P})$, calcium $(\mathrm{Ca})$ and iron (Fe) were detected by EDAX on the surface of native cells, and concentrations of semi-quantified results were shown in EDAX spectra (Figure 6A). After cadmium(II) uptake by live cells and dead cells, some bright dots occurred on the surface (Figure $6 \mathrm{~B}$ and $\mathrm{C}$ ), showing that the cell surface adsorbed cadmium(II) (16.4 and 68.13 atom percentage (at\%), respectively). An increase in the atomic percent of $P$ after cadmium(II) uptake by live and dead cells indicating that cadmium(II) might be deposited in the form of cadmium phosphate. Also, it was observed that cadmium(II) was exchanged with Al present on the surface of native cells. This was in agreement with the findings of Volesky et al. (1993), Aloysius et al. (1999), and Can and Jianlong (2008).

The appearance of $\mathrm{Cl}$ peaks in case of cadmium(II)loaded dead and live biomass could be explained in the light of complexation mechanism. In this connection, Naja and Volesky (2011) reported that cadmium(II) will form the following complexes with chloride ions, $\mathrm{CdCl}^{-}, \mathrm{CdCl}_{2}^{0}$, $\mathrm{CdCl}_{3}^{-}$and $\mathrm{CdCl}_{4}^{-2}$. According to our observations, it can be concluded that the bioadsorption, ion exchange and 

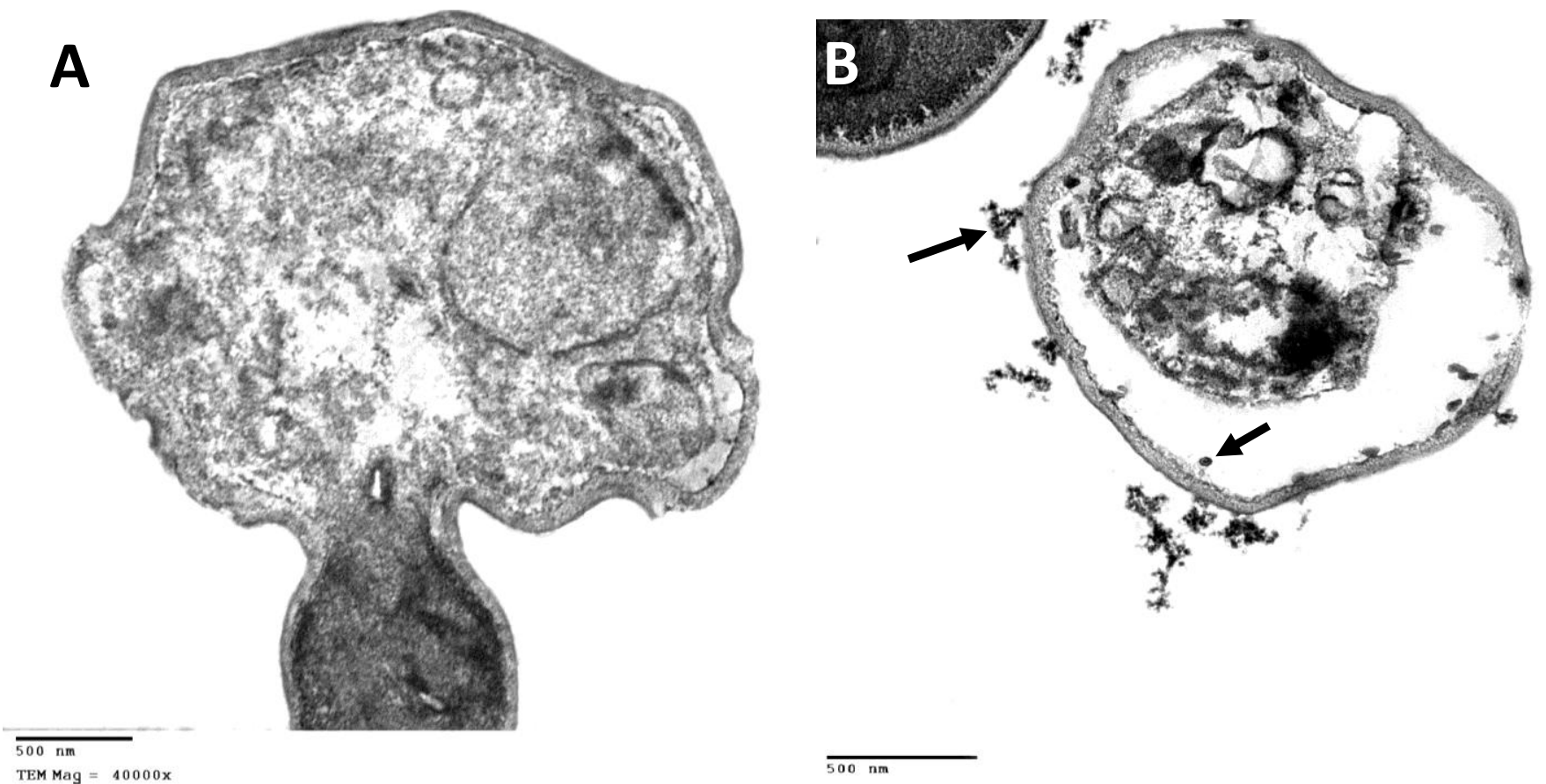

C
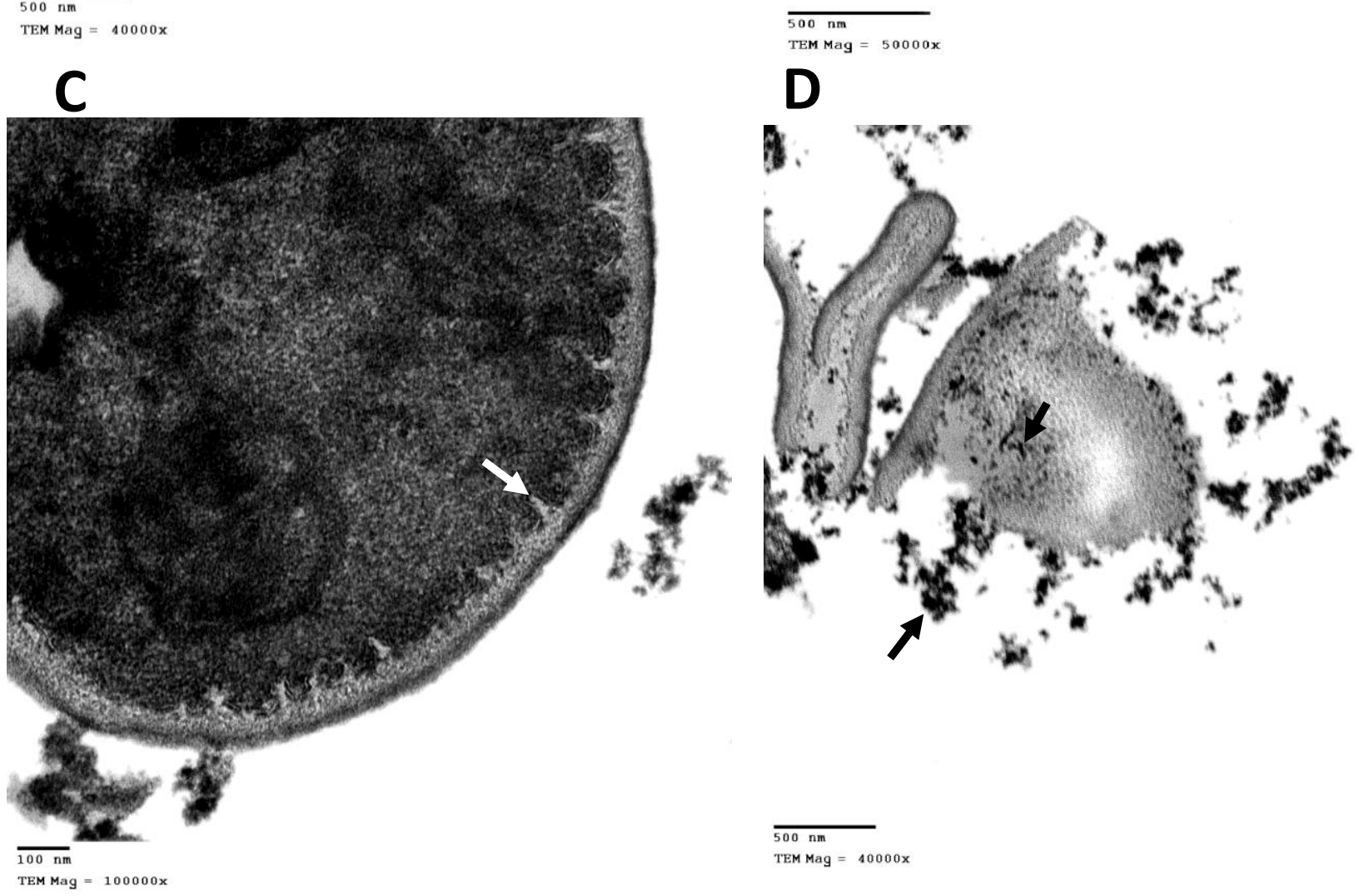

Figure 5. TEM of S. cerevisiae biomass, (A) control; (B) and (C) live cadmium(II) loaded; (D) dead cadmium(II) loaded biomass.

complexation play a role in cadmium uptake. The effect of pretreatments on biosorption of cadmium(II) $S$. cerevisiae is shown in Figure 7. The results revealed that biomass pretreated with ethanol exhibited the maximum uptake capacity (60 mg/g) for cadmium(II) as compared to untreated yeast $(55 \mathrm{mg} / \mathrm{g})$. The higher metal uptake values obtained by ethanol treated yeast cells may be explained by the increase in the availability of binding sites and thus the improvement in the access of metal ions to the metal binding sites of yeast cells (Göksungur et al., 2005). Huang and Huang (1996) suggested an increase in metal biosorption after the 
A

\begin{tabular}{|l|c|c|}
\hline Element & Wt(\%) & At(\%) \\
\hline $\mathrm{Na}$ & 11.56 & 13.99 \\
\hline $\mathrm{Mg}$ & 19.25 & 23.15 \\
\hline $\mathrm{Al}$ & 12.56 & 13.43 \\
\hline $\mathrm{Si}$ & 18.84 & 19.17 \\
\hline $\mathrm{P}$ & 16.72 & 15.32 \\
\hline $\mathrm{Ca}$ & 16.67 & 12.56 \\
\hline $\mathrm{Fe}$ & 4.40 & 2.38 \\
\hline
\end{tabular}
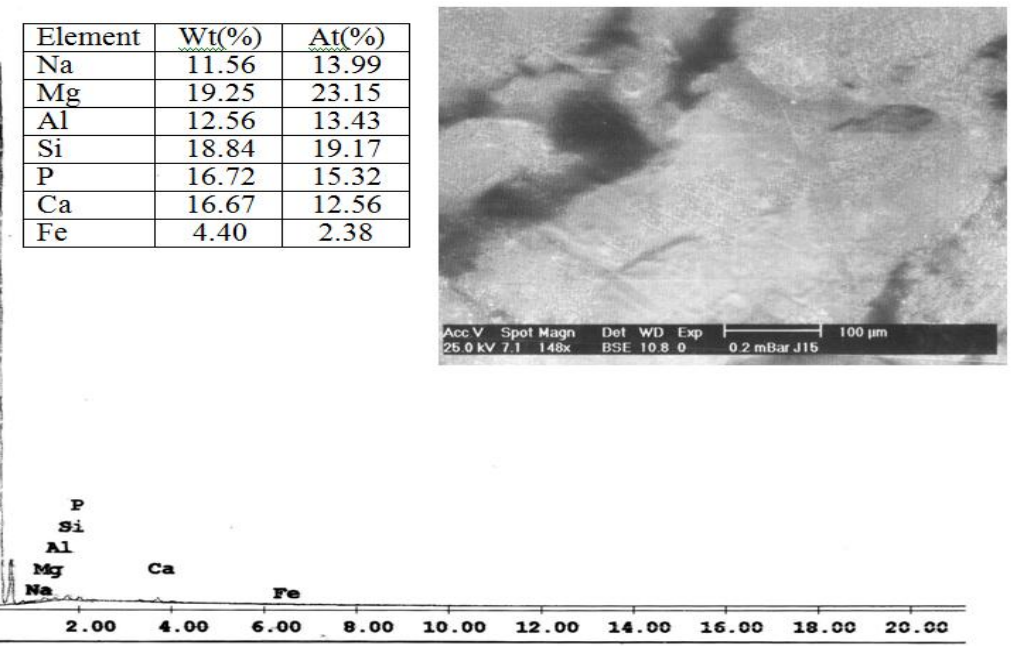

Energy (Kev)

$P$ Si

\begin{tabular}{|l|c|c|}
\hline Element & Wt(\%) & At(\%) \\
\hline $\mathrm{Na}$ & 1.42 & 2.91 \\
\hline $\mathrm{Mg}$ & 1.61 & 3.12 \\
\hline $\mathrm{Si}$ & 3.12 & 5.26 \\
\hline $\mathrm{P}$ & 25.45 & 38.83 \\
\hline $\mathrm{S}$ & 5.10 & 7.51 \\
\hline $\mathrm{C} 1$ & 9.47 & 12.63 \\
\hline $\mathrm{Cd}$ & 39.01 & 16.40 \\
\hline $\mathrm{Ca}$ & 2.37 & 2.79 \\
\hline $\mathrm{Fe}$ & 12.46 & 10.55 \\
\hline
\end{tabular}

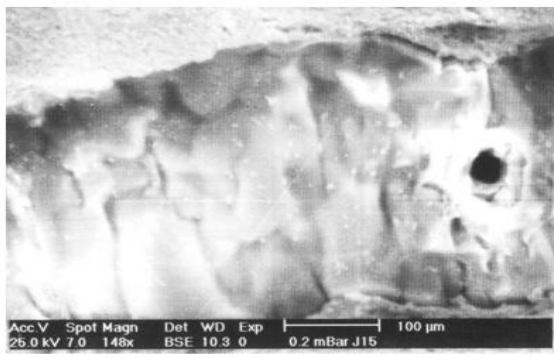

B

Cd
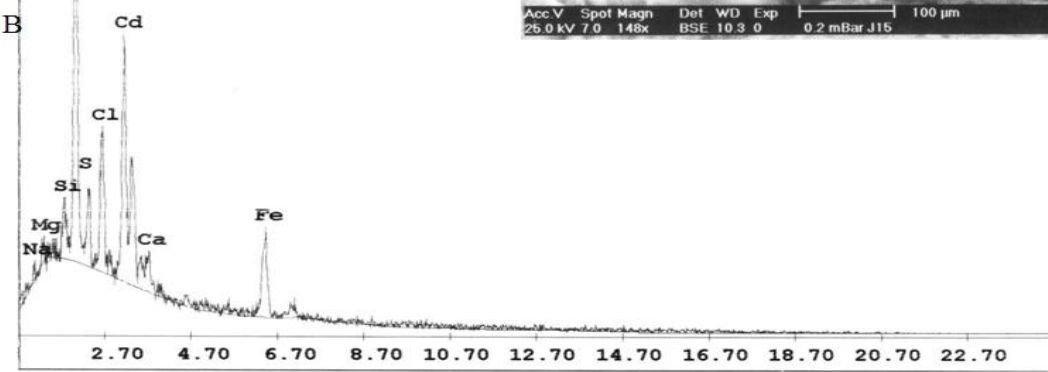

Energy (Kev)

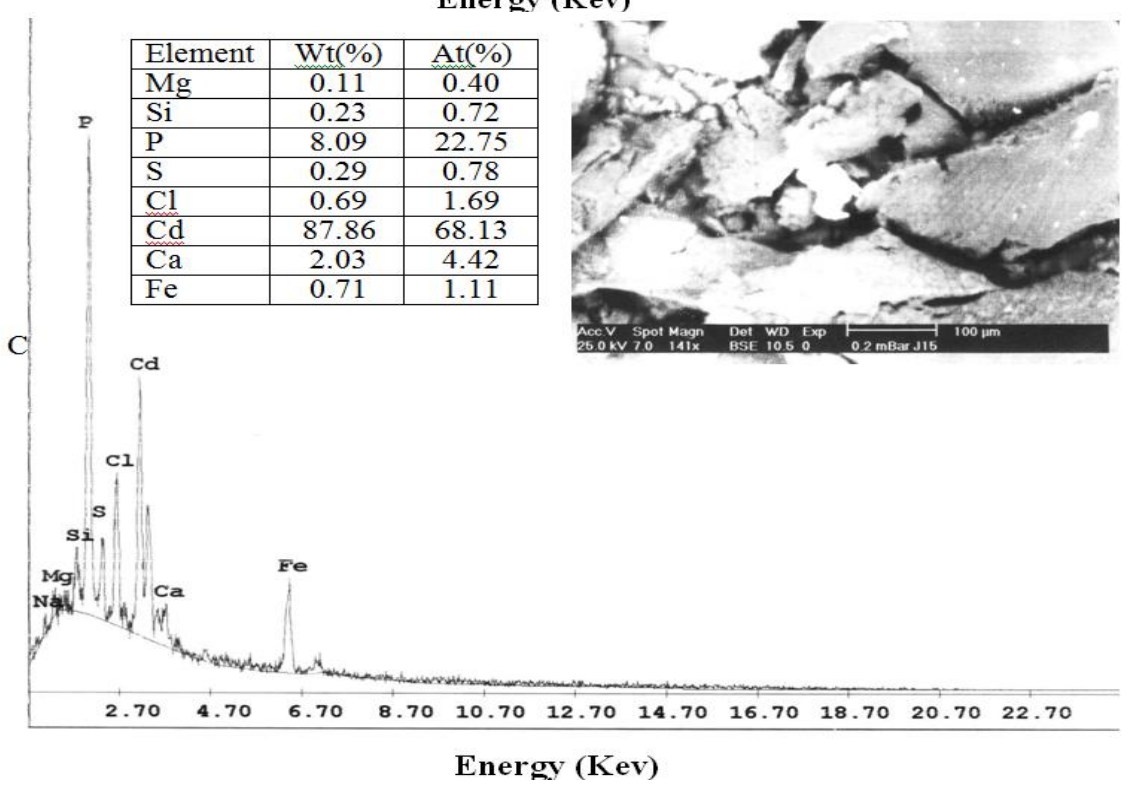

Figure 6. EDAX emitted from native $S$. cerevisiae cells (A); cadmium(II) loaded live cells (B) and cadmium(II) loaded dead cells (C). 


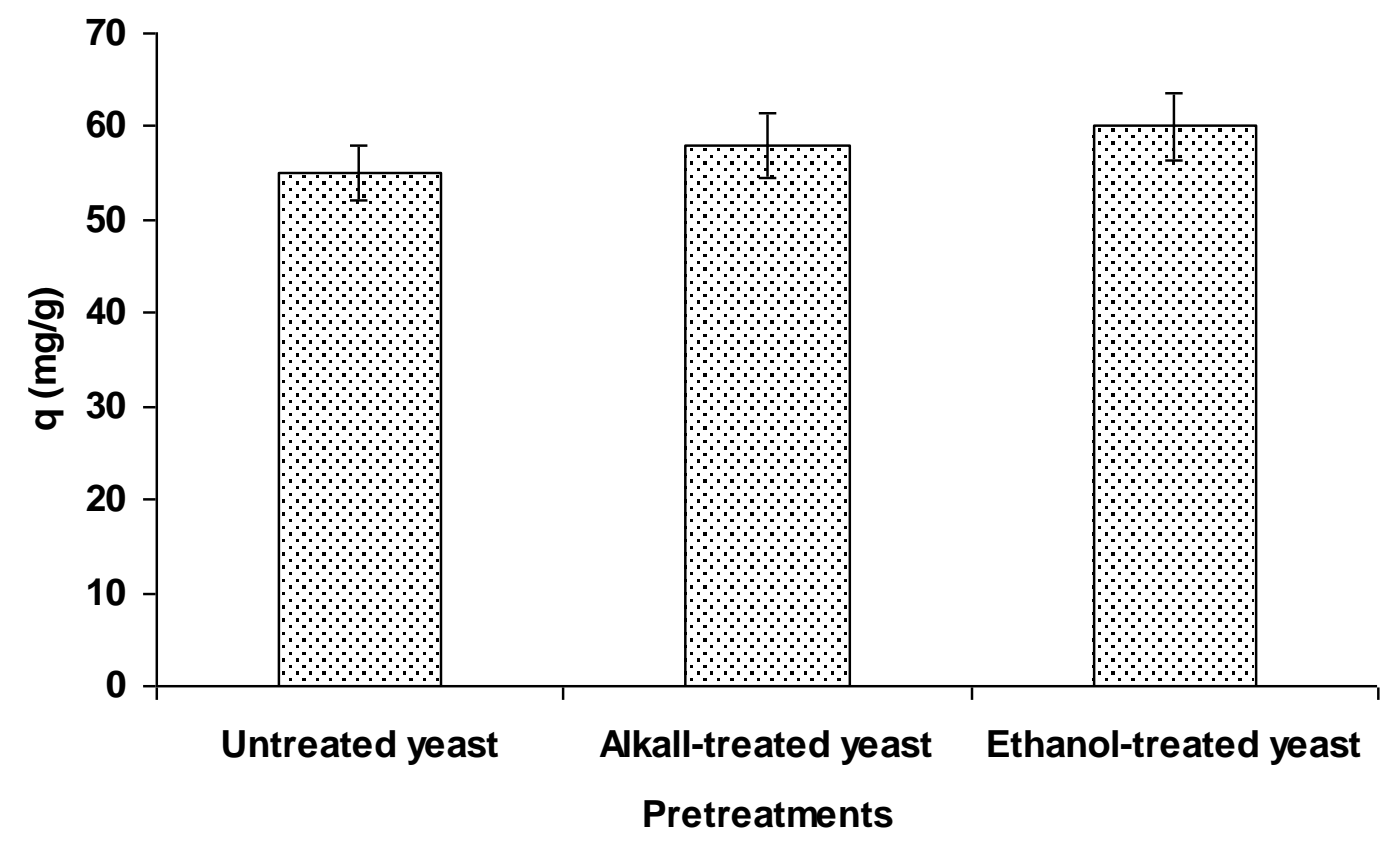

Figure 7. Effect of pretreatments on cadmium(II) uptake capacity of dead S. cerevisiae. Biosorption conditions: $\mathrm{m}$ $=3.0 \mathrm{~g} / \mathrm{L} ; \mathrm{C}_{\mathrm{i}}=250 \mathrm{mg} / \mathrm{L} ; \mathrm{pH}=6.0$ and $\mathrm{pH}=5.0 ; \mathrm{t}=0.5 \mathrm{~h}$.

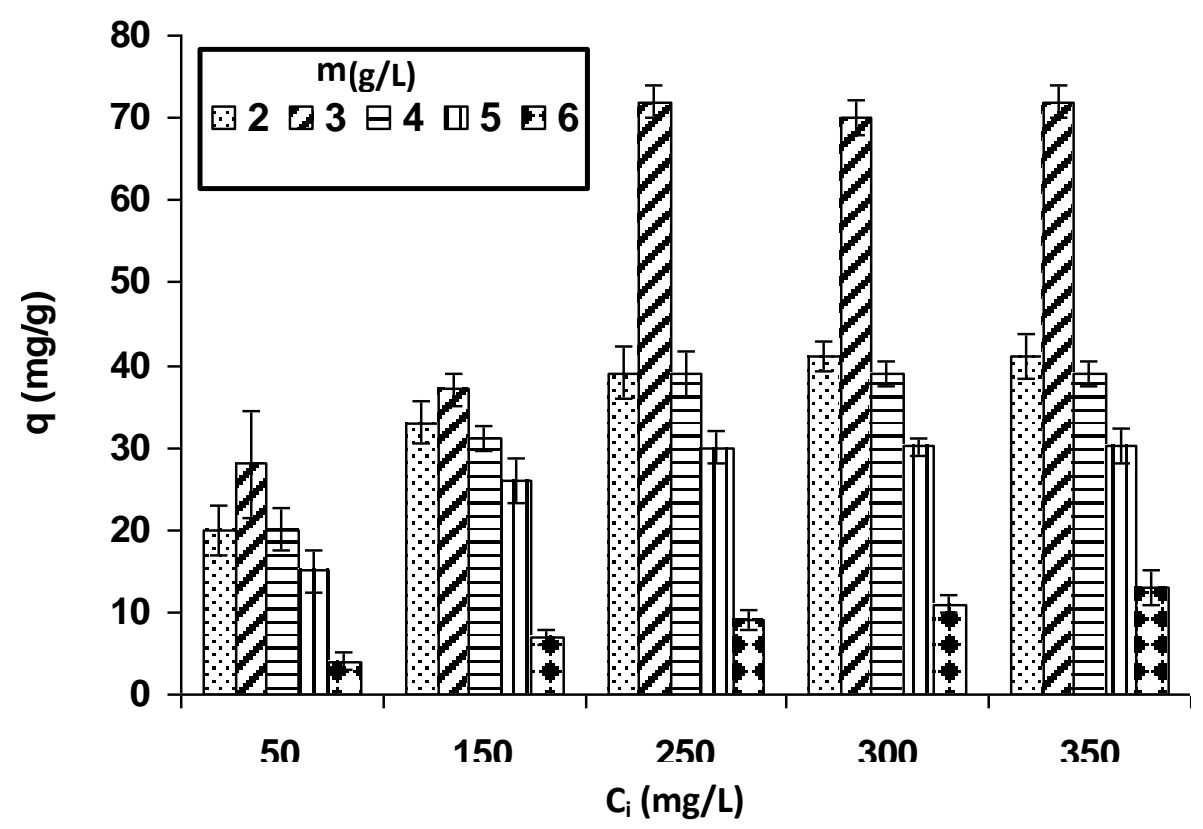

Figure 8. Biosorption of cadmium(II) by ethanol-treated alginate-immobilized dead biomass of $S$. cerevisiae.

biomass pretreatment due to the removal of surface impurities and exposure of available binding sites for metal biosorption.

Cell immobilization offers several advantages, including minimal clogging in continuous systems (Bayramoglu et al., 2003), easy to separate from the reaction system (Annadurai et al., 2007) and can be regenerated and reused for a few cycles (Arica et al., 2001). The most commonly used matrix materials for the immobilization of microbial cells via entrapment are carbohydrate polymers such as alginate (Wu and $\mathrm{Yu}, 2007)$. The results obtained revealed a marked increase in uptake of cadmium(II) by the ethanol-treated, alginate-immobilized biomass over free biomass (Figure 8). Alginate carboxyl groups are 
known to play an important role in metal binding especially with cobalt (Kuyucak and Volesky, 1989). Majdik et al. (2010) reported that the values of cadmium(II) concentration determined at equilibrium are smaller in the case of suspended brewery yeast waste biomass (SBW) and immobilized brewery yeast waste biomass (IBW) $(0.71$ and $0.91 \mathrm{mg}$ cadmium(II)/L, respectively) by comparison with suspended fresh yeast and immobilized fresh yeast $(4.16$ and $2.23 \mathrm{mg}$ cadmium(II)/L, respectively). The difference between SBW and IBW can be attributed to the internal diffusion limitation that occurs when adsorption takes place on immobilized beads. El-Morsy (2004) also mentions that alginate immobilization of alkali-treated biosorbent beads of Cunninghamella elegans results in a nearly two-fold increase in metal ion uptake over free biosorbent. Similarly, Aloysius et al. (1999) concluded that the immobilized cells of live biomass of Rhizopus oligosporus has higher specific cadmium(II) uptake capacity with increasing biomass concentration compared to free cells. In addition, Rani et al. (2010) reported that the adsorption capacity of the immobilized microbial isolates is greater than that of dried biomass in Bacillus sp., Pseudomonas $s p$. and Micrococcus sp. This was attributed to the fact that the dried biomass consists of small particles with low density, poor mechanical strength and little rigidity (Leusch et al., 1995).

The application of fungi and yeast as biosorbents is dependent not only on the biosorptive capacity, but also on the ease with which biomass can be regenerated and reused (Viraraghavan and Srinivasan, 2011). The results obtained herein indicated that $0.5 \mathrm{~mol} \mathrm{HCl}$ solution was able to effectively elute the biosorbed cadmium (II) $(82 \%)$. It was observed that $1.0 \mathrm{mmol} / \mathrm{L}$ EDTA solution was able to elute biosorbed cadmium(II) only to a limited extent (61.4\%) (data not shown). Desorption of heavy metals from metal-loaded biomass is approached by utilizing various eluting agents (Pradhan and Rai, 2001). It was found that $\mathrm{HCl}$ had the best desorption efficiency among the tested chemical agents. Furthermore, acid treatment did not alter the surface characteristics of the biomass with the same binding capacity, except for releasing bound metal from the surface and, in view of this, several adsorption-desorption cycles can be employed (Pradhan and Rai, 2001; Davis et al., 2003). Exploring immobilized $S$. cerevisiae as a biosorbent is feasible for cadmium(II) removal from industrial wastewater, and hydrochloric acid is an inexpensive regeneration agent for regeneration (Zan et al., 2011).

In addition, some physicochemical characteristics of industrial wastewater were ascertained. The temperature of different samples ranged between 25 and $35^{\circ} \mathrm{C}, \mathrm{pH}$ ranged between 6.0 and 8.0 and cadmium(II) ranged between 0.03 and $0.04 \mathrm{mg} / \mathrm{L}$. The ethanol-treated, alginate-immobilized biomass showed strong affinity for removal of cadmium(II) from polluted samples and was able to remove $86 \%$ cadmium(II) from the wastewater.
Rehman and Anjum (2010) also reported that Candida tropicalis was able to remove 56 and $73 \%$ cadmium(II) from wastewater after 6 and 12 days, respectively.

\section{Conclusion}

The biosorption characteristics of cadmium(II) by live and dead biomass of $S$. cerevisiae were investigated. Results indicated that the uptake capacity of dead cells for cadmium(II) was greater than that of live cells and confirm its wider acceptability. This capacity was enhanced when the biomass was treated with ethanol and immobilized on sodium alginate. EDAX and transmission electron microscopic examinations on the biomass indicated the presence of cadmium(II) adsorbed to the surface of the cell wall and inside the cells. S. cerevisiae in its ethanol-treated and alginate-immobilized form also was able to remove up to $86 \%$ of cadmium(II) from industrial waste samples.

\section{REFERENCES}

Aksu Z, Gonen F (2004). Biosorption of phenol by immobilized activated sludge in a continuous packed bed: prediction of breakthrough curves. Process Biochem. 39:599-613.

Aloysius R, Karin MIA, Ariff ABC (1999). The mechanism of cadmium removal from aqueous solution by non-metabolizing free and immobilized live biomass of Rhizopus oligosporus. World J. Microbiol. Biotechnol. 15:571-578.

Annadurai G, Lai FL, Jiunn FL (2007). Biodegradation of phenol by Pseudomonas pictorium on immobilized with chitin. Afr. J. Biotechnol. 6(3):296-303.

APHA (1989). Standard methods for the examination of water and wastewater $\left(18^{\text {th }}\right.$ ed). Washington, DC; APHA.

Arica MY, Kacar Y, Genc O (2001). Entrapment of whit-rot fungus Trametes versicolor in $\mathrm{Ca}$-alginate beads preparation and biosorption kinetic analysis for cadmium removal from an aqueous solution. Bioresour. Technol. 80:121-129.

Awoflou OR, Okonkwo OJ, Merwe RR, Badenhorst J, Jordan E (2006). A new approach to chemical modification protocols of Aspergillus niger and sorption of lead ion. Electron. J. Biotechnol. 9:341-348.

Ayres RU (1992). Toxic heavy metals: Materials cycle optimization. Proceedings of The National Academy of Sciences. USA, 89:815820.

Bayramoglu G, Bektas S, Arica MY (2003). Biosorption of heavy metals on immobilized white rot fungus Trametes versicolor. J. Hazard. Mater. 1:285-300.

Blackwell KJ, Singleton I, Tobin, JM (1995). Metal cation uptake by yeast: A review. Appl. Microbiol. Biotechnol. 43:579-584.

Brady D, Stoll A, Duncan JR (1994). Biosorption of heavy metal cations by non-viable yeast biomass. Environ. Technol.15:429-438.

Can C, Jianlong J (2008). Investigating the interaction mechanism between zinc and Saccharomyces cerevisiae using combined SEMEDX and XAFS. Appl. Microbiol. Biotechnol. 79:293-299.

Cooksey DA (1993). Copper uptake and resistance in bacteria. Mol. Microbiol. 7:1-5.

Dar N, Shakoori AR (1999). Chromium tolerant yeast strains isolated from industrial effluents and their possible use in environmental cleanup. Bull. Environ. Contam. Toxicol. 63:744-750.

Davis TA, Volesky B, Mucci A (2003). A review of the biochemistry of heavy metal biosorption by brown algae. Water Res. 37:4311-4330.

El-Mosry EM (2004). Cunninghamella echinulata a new biosorbent of metal ions from polluted water in Egypt. Mycologia. 96:1183-1189.

Esposito A, Pagnanelli F, Veglio F (2002). pH-related equilibria models for biosorption in single metal systems. Chem. Eng. Sci. 57:307-313. 
Ferraz Al, Tavares T, Teixera JA (2004). Cr (III) removal and recovery from Saccharomyces cerevisiae. Chem. Eng. J. 105:11-20.

Göksungur Y, Üren S, Güvenç U (2005). Biosorption of cadmium and Lead ions by ethanol treated waste baker's yeast biomass. Bioresour. Technol. 96:103-109.

Gonzalez GM, Melville LH, Ferrol N, Lott JN, Azcon A, Peterson RL (2008). Ultrastructural localization of heavy metals in the extraradical mycelium and spores of the arbuscular mycorrhizal fungus Glomus intraradices. Can. J. Microbiol. 54(2):103- 110.

Hallenbeck WH (1986). Human health effects of exposure to cadmium. Experientia suppl. 50:131-137.

Hefnawy MA, Ali MI, Abdul-Ghany SA (2009). Influence of copper and cobalt stress on morphology and ultra-structure of Chaetomium globosom and Stachybotrys chartarum. Aust. J. Basic Appl. Sci. 3(4):3158-3165.

Horikoshi T, Nakajima A, Sakaguchi T (1981). Studies on the accumulation of heavy elements in biological systems. XIX Accumulation of uranium by microorganisms. Appl. Microbiol. Biotechnol. 12:90-96.

Huang C, Huang CP (1996). Application of Aspergillus oryzae and Rhizopus oryzae for Cu (II) removal. Water Res. 9:1985-1990.

Huang C, Huang CP, Morehart A (1990). The removal of Cu (II) from dilute aqueous solutions by Saccharomyces cerevisiae. Water Res. 24:433-439.

Incharoensakdi A, Kitjaharn P (2002). Zinc biosorption from aqueous solution by a halotolerant cyanobacterium, Aphanothece halophytica. Curr. Microbiol. 45:261-264.

Kapoor A, Viraraghavan T, Cullimore D (1999). Removal of heavy metals using the fungus Aspergillus niger. Bioresour. Technol. 70:95104.

Kuyucak N, Volesky B (1989). The mechanism of cobalt biosorption. Biotechnol. Bioeng. 33:823-831.

Lee K, Ueom J (2001). Protection of metal stress in Saccharomyces cerevisiae: Cadmium tolerance requires the presence of two ATPbinding domains of hsp104 protein. Bull. Korean Chem. Soc. 22:514518.

Leusch A, Holan ZR, Volesky B (1995). Biosorption of heavy metals $(\mathrm{Cd}, \mathrm{Cu}, \mathrm{Ni}, \mathrm{Pb}, \mathrm{Zn})$ by chemically-reinforced biomass of marine algae. J. Chem. Technol. Biotechnol. 62:279-288.

Liao VH, Freedman JH (1998). Cadmium - regulated genes from nematode Caenorhabditis elegans. J. Biol. Chem. 273:6218-6222.

Machado MD, Janssens S, Soares HMVM, Soares EV (2008). Removal of heavy metals using a brewer's yeast strain of Saccharomyces cerevisiae: Advantages of using dead biomass. J. Appl. Microbiol. 106(6):1792-1804.

Majdik C, Burca S, Indolean C, Maicaneanu A, Stanca M, Tonk S, Mezey P (2010). Suspended and immobilized brewery waste biomass and commercial yeast as biosorbents for $\mathrm{Cd}$ (II) removal. A thermodynamic Study. Rev. Roum. Chim. 55(11-12):871-877.

Marques PA, Pinheiro HM, Teixeira JA, Rosa MF (1999). Removal efficiency of $\mathrm{Cu}^{2+}, \mathrm{Cd}^{2+}$ and $\mathrm{Pb}^{2+}$ by waste brewery biomass: $\mathrm{pH}$ and cation association effects. Desalination 124:137-144.

Matheickal JT, Yu Q (1999). Biosorption of lead (II) and copper (II) from aqueous solution by pre-treated biomass of Australian marine algae. Bioresour. Technol. 69: 223-229.

Magyarosy A, Laidlaw RD, Kilaas R, Echer C, Clark DS, Keasling JD (2002). Nickel accumulation and nickel oxalate precipitation by Aspergillus niger. Appl. J. Microbiol. Biotechnol. 14:240-246.

Naja G, Volesky B (2011). The mechanism of metal cation and anion biosorption. In: Microbial biosorption of metals. Kotrba P., Mackova M., Macek T. (Eds.). Springer, Germany, pp.19-58.

Nies DH (1999). Microbial heavy metal resistance. Appl. Microbiol. Biotechnol. 51:730-750.

Osumi M (1998). The ultrastructure of yeast: Cell wall structure and formation. Micron 29:207-233.

Özer A, Özer D (2003). Comparative study of the biosorption of $\mathrm{Pb}$ (II), $\mathrm{Ni}$ (II) and $\mathrm{Cr}$ (VI) ions onto Saccharomyces cerevisiae: Determination of biosorption heats. J. Hazard. Mater. 100:219-229.

Park JK, Lee JW, Jung JY (2003). Cadmium uptake capacity of two strains of Saccharomyces cerevisiae cells. Enzyme Microb. Technol. 33:371-378.
Pearce DA, Sherman F (1999). Toxicity of copper, cobalt and nickel salts is dependent on histidine metabolism in the yeast Saccharomyces cerevisiae J. Bacteriol. 181(16):4774-4779.

Pradhan S, Rai LC (2001). Copper removal by immobilized Microcystis aeruginosa in continuous flow columns at different bed heights: Study of the adsorption/desorption cycle. World J. Microbiol. Biotechnol. 17:829-832.

Rani MJ, Hemambika B, Hemapriya J, Rajesh kannan V (2010): Comparative assessment of heavy metal removal by immobilized and dried bacterial cells: A biosorption approach. Afr. J. Environ. Sci. Technol. 4:77-83.

Rehman A, Anjum MS (2010). Cadmium uptake by yeast, Candida tropicalis, isolated from industrial effluents and its potential use in wastewater clean-up operations. Water, Air, Soil Pollut. 205:149-159.

Reynolds ES (1963). The use of lead citrate at high pH as an electron opaque stain in electron microscopy. J. Cell Biol. 17:208-212.

Rothschild LJ, Mancinelli RL (2001). Life in extreme environments. Nature 409:1092-1101.

Scott JA, Plamer SJ (1995). Sites of cadmium uptake in bacteria used for biosorption. Appl. J. Microbiol. Biotechol. 33:221-225.

Shakoori AR, Makhdoom M, Hag RU (2000). Hexavalent chromium reduction by a dichromate-resistant Gram-positive bacterium isolated from effluents of tanneries. Appl. Microbiol. Biotechnol. 53: 348-351.

Shao Z, Sun A (2007). Intracellular sequestration of manganese and phosphorus in a metal-resistant fungus Cladosporium cladosporioides from deep-sea sediment. Extremophiles 11(3):435443.

Sola S, Barria T, Martin A (1998). Cadmium and lead in pork and duck liver pastes produced in Spain. Food Addit. Contam. 15:580-584.

Sptempack JG, Ward RT (1969). An improved staining for electron microscopy. J. Cell Biol. 22(3):697-701.

Suh JH, Yun JW, Kim DS (1998). Comparison of $\mathrm{Pb}^{2+}$ accumulation characteristics between live and dead cells of Saccharomyces cerevisiae and Aureobasidium pullulans. Biotechnol. Lett. 20(3): 47251.

Tsekova K, Petrov G (2002). Removal of heavy metals from aqueous solution using Rhizopus delemar mycelia in free and polyurethanebound form. Zeitschrbt für Naturforschung 57:629-633.

Veglio F, Beolchini F (1997). Removal of metals by biosorption: A review. Hydrometallurgy 44:301-316.

Viraraghavan T, Srinivasan A (2011). Fungal biosorption and biosorbents. In Kotrba P., Mackova M., Macek T. (Eds.). Microbial biosorption of metals. Springer, Netherlands- Dordrecht, pp.143-158.

Volesky B (1990). Biosorption of heavy metals CRC Press, Boston, USA, pp.3-5.

Volesky B, May H, Holan ZR (1993). Cadmium biosorption by Saccharomyces cerevisiae. Biotechnol. Bioeng. 41:826-829.

Wang J, Chen C (2006). Biosorption of heavy metals by Saccharomyces cerevisiae: A review. Biotechnology Adv. 24:427-451.

Wu J, Yu HQ (2007). Biosorption of 2, 4-dichlorophenal from aqueous solution by Phanerochaete chrysosporium biomass: Isotherms, kinetics and thermodynamics. J. Hazard. Mater. 93:253-259.

Yan G, Viraraghavan $T$ (2000). Effects of pretreatment on the bioadsorption of heavy metals on Mucor rouxii. Water SA 26(1):119123.

Zan F, Huo S, XI B, Zhao X (2011). Biosorption of $\mathrm{Cd}^{+2}$ and $\mathrm{Cu}^{+2}$ on immobilized Saccharomyces cerevisiae. Front. Environ. Sci. Eng. China (3 February) pp.1-8.

Zouboulis Al, Rousou EG, Matis KA, Hancock CC (1999). Removal of toxic metals from aqueous mixtures. Part I: Biosorption. J. Chem. Technol. Biotechnol. 74:429-436. 